\title{
Człowieczeństwo Syna Bożego we wcieleniu według synoptyków
}

Wiara w osobowe zjednoczenie w Jezusie Bóstwa i człowieczeństwa stanowi wyzwanie dla teologii. Jej wypowiedzi mają bowiem zachować jedność obydwu elementów oraz troszczyć się o integralność każdego z nich. Poprzedzające sobór chalcedoński dyskusje oraz dzieje recepcji jego nauki pokazują, że drugie zadanie jest trudniejsze niż pierwsze, a błędy w rozumieniu tej integralności pociągają za sobą niedostatki w pojmowaniu jedności. Prawdziwość zjednoczenia Bóstwa i człowieczeństwa zakłada, że zachowują one swoje własności.

\section{Nieostrość pojęcia w świetle Biblii}

Jak z perspektywy pism Nowego Testamentu, a zwłaszcza Ewangelii synoptycznych, można mówić o człowieczeństwie Jezusa? Formuła Symbolu nicejskiego - „dla nas ludzi i dla naszego zbawienia zstąpił i przyjął ciało, stał się człowiekiem ('̇v $\alpha v \theta \rho \omega \pi \eta ́ \sigma \alpha \nu \tau \alpha)$, cierpiał i zmartwychwstał trzeciego dnia, wstąpił do nieba, przyjdzie sądzić żywych i umarłych" ${ }^{1}$ - nie odzwierciedla koncentracji narracji ewangelicznej na ziemskim życiu Jezusa od Jego chrztu

1 Sobór Nicejski I, Wyznanie wiary 318 Ojców, w: Dokumenty soborów powszechnych, t. 1, red. A. Baron, H. Pietras, Kraków 2003, s. 24-25. 
w Jordanie aż do męki i śmierci w Jerozolimie. Dopiero nowsze traktaty teologii dogmatycznej, wychodząc od obrazu Ewangelii, poświęcają obszerne rozdziały publicznej działalności Jezusa ${ }^{2}$. Na ten zwrot w chrystologii wpłynął rozwój studiów biblijnych i pojawienie się nowych metod w hermeneutyce biblijnej, a w samej teologii systematycznej doceniono nie tylko tajemnicę paschalną Chrystusa, ale całe Jego ziemskie życie. We współczesnych traktatach chrystologicznych poświęca się więcej uwagi znaczeniu tego, co działo się między Jego narodzeniem a śmiercią, a nawet kwestiom związanym z Jego ludzkim dojrzewaniem, charakterystycznym rysom Jego osobowości oraz Jego relacjom międzyosobowym, gestom i emocjom. Wśród cech charakterystycznych dla ludzkiej osobowości, które zgodnie poświadczają różne pisma Nowego Testamentu, są wyliczane: całkowite oddanie misji; wrażliwość na potrzeby ludzi; wolność nieodrzucająca norm i tradycji, lecz odkrywająca ich pełniejszy sens; synowska miłość do Boga $\mathrm{Ojca}^{3}$. W interpretacjach skupiających się na pojedynczych księgach są badane wzmianki o Jego percepcji, uczuciach, emocjach i cielesności w celu określenia ich funkcji literackiej i znaczenia teologicznego ${ }^{4}$.

Często zakłada się jednoznaczność rozróżnienia tego, co boskie, i tego, co jest właściwe ludziom. To jednak nie jest oczywiste w świetle tekstów biblijnych. $Z$ jednej strony niektóre $\mathrm{z}$ nich stwierdzają, że Bóg nie jest jak ludzie, którzy podlegają zmiennym uczuciom (por. Lb 23,19; $1 \mathrm{Sm} \mathrm{15,29;} \mathrm{Oz} \mathrm{11,9),} \mathrm{oraz} \mathrm{że} \mathrm{nie}$ można Go zamknąć w ludzkich wyobrażeniach kształtowanych przez czas i przestrzeń (por. $1 \mathrm{Krl}$ 8,27; Hi 10,5; Jr 23,23-24). Jego transcendencję mocno afirmuje Deutero-Izajasz (por. Iz

2 Np. G. Strzelczyk, Traktat o Jezusie Chrystusie, w: Dogmatyka, t. I, red. E. Adamiak, A. Czaja, J. Majewski, Warszawa 2005, s. 235-499.

3 W ten sposób tamże, s. 275-280.

4 Tak ukierunkowaną analizę tekstu Marka przedstawia S. Villota Herrero, La dimensión corporal-emocional en Jesús y en los hombres según San Marcos, „Antonianum” 91 (2016), s. 103-127. 
40,12-16). Z drugiej strony, nie brakuje w Starym Testamencie antropopatyzmów. Bóg żałuje podjętego postanowienia i cofa ogłoszoną już decyzję (por. Rdz 6,6-7; $1 \mathrm{Sm} \mathrm{15,35;} 1 \mathrm{Krn} 21,15$ ); gniewa się (por. Lb 25,11; Ps 78,58; 79,5; 85,6; Jr 3,5; 10,10) i zazdrości (por. Wj 20,5; 34,14; Lb 25,11; Pwt 4,24; 5,9; 6,15; Ps 78,58; Na 1,2). W każdej z trzech głównych części Biblii hebrajskiej (Prawo, Prorocy i Pisma) jest On przedstawiony jako podmiot bólu oznaczonego przez formy z podstawą wyrazową ' $C B$ (por. Rdz 6,2.5-6; Iz 63,8-10.16; Ps 78,35.38.40), które oznaczają wielkie cierpienie ludzi z powodu zagrożenia życia ich najbliższych lub ich własnego (por. $\operatorname{Rdz} 3,16.17 ; 34,7 ; 45,4-5$; 1 Sm 20,3.34; 2 Sm 19,3) .

Antropomorfizmy nie są reliktem jakiejś pierwotnej postaci wierzeń Izraelitów ${ }^{6}$. Przypisywanie Bogu cech ludzkich pasuje

5 Jeśli sprowadza się egzystencję ludzką do aspektów negatywnych, to w tekstach Ewangelii można znaleźć wiele świadectw o człowieczeństwie jako doświadczaniu braków czy niedoskonałości: cierpiał głód (por. Mt 4,2; 21,18), odczuwał pragnienie (por. J 4,7; 19,28) i zmęczenie (por. J 4,6), potrzebował snu (por. Mk 4,38). Łukasz zwraca uwagę na fizjologię lęku (por. Łk 22,44), Jan zaś na analogiczne znaki śmierci (por. J 19,34). Wzmianka o tym, że Jezus „Wzrastał w mądrości” (por. Łk 2,52), świadczy o Jego rozwoju umysłowym. Poprosił o informacje (por. Mk 5,30-33; 9,21), a nawet wyznał niewiedzę odnośnie do czasu powtórnego przyjścia (Mk 13,32). Wszystkie Ewangelie jednoznacznie przedstawiają śmierć przez ukrzyżowanie jako realną. Por. R.H. Culpepper, The Humanity of Jesus the Christ: An Overview, „Faith and Mission” 5 (1988) 2, s. 14-27.

6 Taką zależność między unikaniem antropomorfizmów a późniejszym pochodzeniem świadectw można stwierdzić dopiero w przekładach Biblii i jej parafrazach, kiedy w okresie judaizmu Drugiej Świątyni - pod wpływem konfrontacji religii Izraela z hellenistyczną filozofią grecką, a szczególnie z alegoryzującymi nurtami filozofii poplatońskiej - antropomorfizujące określenia zastępowano terminologią teologicznie mniej kłopotliwą. Zakres tych zmian jest przedmiotem współczesnej debaty, zaczynając od pionierskich prac powstałych blisko połowy XX wieku: C.T. Fritsch, The Anti-anthropomorphisms of the Greek Pentateuch, Princeton 1943; J.I. Schochet, The Treatment of Anthropomorphism in the 
dobrze do późniejszego stadium rozwoju religii Izraela - w okresie już od niewoli babilońskiej - występującej przeciw wierzeniom pogan $\mathrm{z}$ ich werbalnymi i plastycznymi wyobrażeniami bóstw według modelu ludzi lub zwierząt. Warto zauważyć, że autorzy biblijni unikają tych drugich, a mianowicie teriomorfizmów - rozpowszechnionych we wszystkich religiach ludów sąsiednich ${ }^{7}$. Natomiast śmiało sięgając po te pierwsze, poszukują środków słownego wyrazu dla wiary w osobowego Boga w ewidentnym kontraście do sposobów reprezentowania bóstw pogańskich. Sformułowany w prawie Mojżeszowym zakaz sporządzania materialnych modeli Boga paradoksalnie przyczynił się do ubogacenia i rozwinięcia Jego słownych obrazów, które miały uwydatnić, że nie trzyma się On z dala od swojego krnąbrnego i niewiernego ludu, lecz bardzo troszczy się o jego życie ${ }^{8}$. Wymownym przykładem takiej antropomorfizującej apologii jest ironiczna krytyka podjęta przez psalmistę i wymierzona przeciw religiom pogańskim:

Ich idole to srebro i złoto, robota rąk ludzkich.

Mają usta, a nie mówią.

Mają oczy, a nie widzą.

Mają uszy, a nie słyszą.

Mają nozdrza, a nie czują.

Ręce mają, a nie dotykają.

Nogi mają, a nie chodzą.

Nie wychodzą głosy z ich gardła.

Targum Onkelos, Hamilton 1966. Dobre omówienie tej problematyki oferuje A. Kuśmirek, Antropomorfizmy w targumach Pięcioksięgu, „Słowo Krzyża" 3 (2009), s. 109-123.

7 Porównanie JHWH do lwa wypadającego z zarośli Jordanu jest figurą poetycką oznaczającą niespodzianą zagładę ludów pogańskich (por. Jr 49,19; 50,44).

8 Por. E.M. Yamauchi, Anthropomorphism in Ancient Religions, „Bibliotheca Sacra" 125 (1968) 497, s. 29-44. 
Jak oni staną się ich twórcy,

Każdy, który im zaufał (Ps 115,4-8) .

Cechy i działania uznawane powszechnie za właściwe ludziom - aktywność sensoryczna i przemieszczanie się - nie są przeciwstawione prawdziwemu Bogu i właściwym dla Niego działaniom, ale są Mu przypisane jako własne i autentyczne czynności. Natomiast całość relacji „ludzie - bóstwa pogańskie” jest zilustrowana przez podobieństwo między dziełami a ich twórcami: nie słyszą, nie widzą, nie mówią. Charakter tego podobieństwa ujawnia się wyraźniej w drugiej części psalmu. Działania prawdziwego Boga stają się pierwowzorem animującym aktywność Jego wyznawców. Negatywny sąd o religiach pogańskich stanowi okazję dla potwierdzenia własnej wiary oraz podkreślenia tego, co sprawia, że radykalnie różni się ona od fałszywych wierzeń. Na tym tle Bóg Izraela ukazany jest jako żywy Bóg i Bóg żywych, tak że tylko oni mogą Go wielbić, dlatego że jak On są żywi, a nie umarli jak wyznawcy bogów fałszywych (por. Ps 115,16-18).

Teksty Starego Testamentu nie pozwalają zatem na wytyczenie wyraźnych granic między tym, co charakteryzuje naturę boską, a tym, co przynależy do natury ludzkiej. To przeciwstawienie pojawia się dopiero w okresie bliskim powstaniu Nowego Testamentu, choć jeszcze nie wpływa mocno na teologię jego pism. Wpływ ten ujawnia się wyraźnie w alegoryzującej interpretacji tekstów Starego Testamentu, prowadzonej w środowisku aleksandryjskim.

\section{Termin „człowieczeństwo” i jego znaczenie w I wieku}

W wyznaniu wiary, w którym sobór chalcedoński definiuje relacje między Bóstwem a człowieczeństwem Jezusa, rozróżnienie

9 Tłumaczenia tekstów biblijnych są własne. 
między tymi dwoma elementami jest oczywiste na poziomie leksykalnym. Rzeczownik „człowieczeństwo” (’’ $v \theta \rho \omega \pi$ ó $\eta \varsigma)$ użyty jest aż trzy razy: „Zgodnie ze świętymi Ojcami wszyscy jednomyślnie uczymy wyznawać, że jest jeden i ten sam Syn, Pan nasz Jezus Chrystus, doskonały w Bóstwie i doskonały w człowieczeństwie ( $\alpha v \theta \rho \omega \pi$ ó $\eta \tau \imath)$, prawdziwy Bóg i prawdziwy człowiek, złożony z duszy rozumnej i ciała, współistotny Ojcu co do Bóstwa i współistotny nam co do człowieczeństwa ( $\left.\dot{\alpha} v \rho \rho \omega \operatorname{có}^{\prime} \eta \tau \alpha\right)$, «we wszystkim nam podobny prócz grzechu», przed wiekami zrodzony z Ojca co do Boskości, w ostatnich czasach narodził się

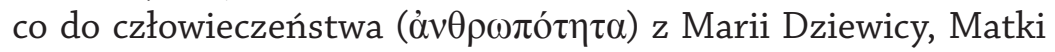
Bożej, dla nas i dla naszego zbawienia" ${ }^{10}$.

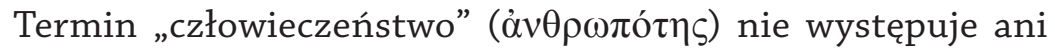
w Septuagincie, ani w księgach Nowego Testamentu, ani nawet w pismach ojców apostolskich. Jego nieobecność kontrastuje

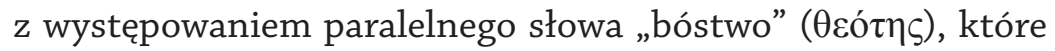
pojawia się jeden raz w listach Pawła (1 Kol 2,9) oraz ośmiokrotnie w Pasterzu Hermasa ${ }^{11}$. Sytuacja ta nastręcza trudności w łączeniu zacytowanego fragmentu z wyraźnie zdefiniowanymi tekstami Nowego Testamentu.

W pierwszych wiekach rzeczownik „człowieczeństwo” pojawia się w pismach autorów związanych z Aleksandrią ${ }^{12}$. Cztery razy występuje on $w$ dziełach egzegetyczno-teologicznych Filona. Ten platonizujący filozof żydowski posługuje się nim

10 Sobór Chalcedoński, Definicja wiary 11, w: Dokumenty soborów powszechnych, t. 1, s. 222-223.

11 W Liście do Kolosan (2,9) oraz w Pasterzu Hermasa (10, 1, 4 [2x]; $10,1,5 ; 10,1,6 ; 11,1,5 ; 11,1,10[2 x] ; 11,1,14)$ jest synonimiczny z rzeczownikami $\theta \varepsilon o ́ \varsigma$ i кúpıs, oznaczającymi Boga, ponieważ razem z nimi tworzy paralelizmy.

12 Po Filonie z Aleksandrii także u innych związanych z tym ośrodkiem myśli hellenistycznej okresu rzymskiego: Wettiusz Walens (II w.), Sekstus Empiryk (II/III w.) i Plotyn (III w.). 
w sensie odpowiadającym uniwersaliom ${ }^{13}$, kiedy przedstawia jako absurdalny pogląd, że śmierć pojedynczego człowieka mogłaby oznaczać „zniszczenie tego wszystkiego, do czego [ten

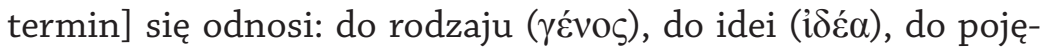
cia $(\dot{\varepsilon} v v o ́ \eta \mu \alpha)$ lub do czegokolwiek innego w ten sposób nazywanego" (Deter. 76) ${ }^{14}$. Aleksandryjski egzegeta stwierdza, że o ograniczeniach człowieczeństwa zapominają ludzie, którzy jak faraon nie znają prawdziwego Boga (por. Wj 5,2; Poster. 115). Natomiast stała pamięć o takim jego sensie powstrzymuje ludzi cnotliwych przed wzniosłymi i aroganckimi myślami (por. Spec.

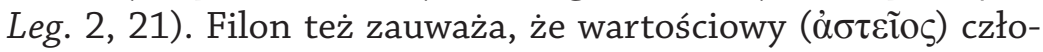
wiek zajmuje jakby pośrednią pozycję, ponieważ „nie jest ani Bogiem ani człowiekiem, lecz jest związany z dwoma kresami: przez człowieczeństwo z gatunkiem śmiertelnym, a przez cnotę z niezniszczalnością" (Somn. 2, 230). W tych trzech kolejnych wzmiankach pojęcie człowieczeństwa ma już węższe znaczenie, gdyż konotuje ułomności każdego człowieka, które wynikają z jego przynależności do rodzaju ludzkiego.

\section{Człowieczeństwo Jezusa z perspektywy pochodzenia}

Filonowemu pojmowaniu człowieczeństwa przeciwstawionemu idei bóstwa tylko w ograniczonym zakresie odpowiada interpretacja rozróżniająca obraz Chrystusa w Ewangelii św. Mateusza i Jego przedstawienie w Ewangelii św. Jana. Dlaczego na początku pojawia się porównanie chrystologii tylko tych dwóch Ewangelii? Od II wieku utrwala się przekonanie o bezpośrednim

13 Por. H.A. Wolfson, Philo: Foundations of Religious Philosophy in Judaism, Christianity, and Islam, t. 1, Cambridge 1947, s. 412.

14 Tłumaczenie Filona własne z tekstu greckiego w Filone di Alessandria, Tutti i trattati del commentario allegorico alla Bibbia. Testo greco a fronte, red. R. Radice, Milano 2005. 
pochodzeniu tych dwóch ksiąg od apostołów, stąd też czytane, komentowane i porównywane są częściej niż dwie inne ${ }^{15}$. To najwcześniejsze zestawienie znajduje się u Ireneusza z Lyonu, który afirmując jedność Bożego objawienia przyniesionego przez czterokształtną Ewangelię, odwołuje się do biblijnej symboliki czterech istot żywych (por. Ez 1,5-6.10; Ap 4,6-7: „Zwierzę pierwsze - powiada - podobne do lwa charakteryzujące jego skuteczną moc, suwerenność i królewskość. Drugie (zaś) podobne do cielca, co wskazuje na godność ofiarnika i kapłana. Trzecie zwierzę, mające oblicze jakby człowieka, co jasno opisuje jego przyjście jako człowieka. A czwarte podobne do orła latającego, co oznacza spływającą na Kościół łaskę Ducha. Ewangelie zatem odpowiadają tym figurom, na których siedzi Chrystus" (Adv. haer. $3,11,8)^{16}$.

Następnie Ireneusz charakteryzuje cztery Ewangelie w kolejności wymienienia czterech istot żywych: Jan, Łukasz, Mateusz i Marek. Istoty scharakteryzowane jako pierwsza i trzecia są skojarzone z Ewangeliami Jana i Mateusza, które na początku mówią o Boskim i ludzkim pochodzeniu Jezusa: „Jedna z nich opisuje przedwieczne, pełne mocy i chwały Jego narodzenie i zaczyna tak: Na początku było Słowo, A Słowo było u Boga, a Bogiem było Słowo [...]. Mateusz zaś opowiada o narodzeniu Chrystusa jako człowieka: Rodowód Jezusa Chrystusa, Syna Dawida, Syna Abrahama $(1,1)$ i znów: A z narodzeniem Chrystusa było tak $(1,18)$. Ewangelia ta przedstawia więc Chrystusa w ludzkiej postaci i dlatego na wszystkich jej kartach występuje Chrystus jako cichy i pokornego serca" (Adv. haer. 3,11,8) ${ }^{17}$.

W początkowych perykopach Mateusza obraz Jezusa odpowiadałby zatem rozumieniu człowieczeństwa w sensie znanym

${ }^{15}$ W niektórych kodeksach te dwie Ewangelie są umieszczane przed tekstami Marka i Łukasza.

16 Antologia patrystyczna, tłum. A. Bober, Kraków 1966, s. 44. Kolejność zwierząt odpowiada ich wyliczeniu w ostatniej księdze Pisma Świętego.

17 Tamże, s. 45. 
z pism Filona, a mianowicie przynależności do ludzkości oraz słabej i niskiej kondycji człowieka. Ten obraz Chrystusa odróżniony jest od Jego wizerunku u Jana, który wyraźnie zaznacza Jego boskie rysy oraz mocne i królewskie pochodzenie.

Rozróżnienie Ireneusza jest dalekie od koncepcji chrystologii oddolnej i odgórnej. Jego symboliczna interpretacja przedstawia bowiem dwa obrazy jako dwie strony jednej i tej samej rzeczywistości, a nie jako konkurujące ze sobą wizje, z których niższa miałaby być wyparta przez wyższą. Dopiero współczesna egzegeza traktuje odmiennie różnice między tymi obrazami. Kiedy w drugiej połowie XIX wieku historyczne pierwszeństwo wśród autorów Ewangelii przypisano Markowi (wraz z hipotetycznym dokumentem Q), wtedy miejsce dwóch uzupełniających się wizerunków Jezusa - z pochodzeniem boskim (Jan) oraz ludzkim (Mateusz) - zajęły hipotezy o wcześniej ukształtowanej chrystologii oddolnej oraz dominującej później odgórnej ${ }^{18}$. Od takiego

18 Wraz z podważeniem bezpośredniego apostolskiego pochodzenia Ewangelii Mateusza i Jana, a pośredniego - Marka i Łukasza, najpierw odrzucono czwartą Ewangelię jako wiarygodne źródło o życiu Jezusa, przypisując Markowi oraz dokumentowi wspólnemu dla Mateusza i Łukasza większą wartość historyczną niż późniejszym Ewangeliom synoptycznym. Marek miał przedstawiać ziemskiego, historycznego Jezusa, który tylko stopniowo odsłaniał swoją tożsamość i cel swojej działalności. Etapowość objawienia miała wychodzić naprzeciw trudnościom uczniów w rozumieniu rzeczywistej natury Jego mesjańskości, a ich trudności wynikać z przywiązania do koncepcji mesjanizmu politycznego. Na początku XX wieku podano w wątpliwość historyczność tej pedagogii ziemskiego Jezusa. Motyw niezdolności uczniów razem z nakazami milczenia skierowanymi do adresatów Jego działalności (demony, uzdrowionych i uczniów) włączono do koncepcji tzw. sekretu mesjańskiego (Messiasgeheimnis), która miałaby godzić historyczny obraz Jezusa jako człowieka z późniejszymi warstwami nakładanymi na ten pierwotny wizerunek przez wyznawców Jego mesjańskości i synostwa Bożego. 
ujmowania rozwoju chrystologii nie są też wolne opracowania teologii czwartej Ewangelii ${ }^{19}$.

Zmiana w podejściu do synoptycznych genealogii ilustruje przemiany w egzegezie już z pozytywnymi rezultatami. Od czterech dekad zwraca się większą uwagę na literacki charakter Pisma Świętego. W przypadku rodowodu Jezusa można dotrzeć nie tyle do Filonowej idei człowieczeństwa, przeciwstawionej pojęciu Boskości, ile do znaczenia Jego przynależności do rodzaju ludzkiego w sensie Ireneuszowego rozumienia genealogii jako wprowadzenia do głównego tematu całej Ewangelii. Wcześniej dyskutowano historyczność rodowodów z powodu rozbieżności między ich dwiema wersjami oraz niezgodności ze starotestamentowymi listami pochodzenia osób wymienionych w tych dwóch wykazach. Obecnie egzegeza stawia za cel nie rekonstrukcję historycznego drzewa genealogicznego Jezusa, lecz traktuje genealogie jako gatunek literacki, który wyraża odmienną teologię Mateusza i Łukasza ${ }^{20}$. Taka prezentacja związku Jezusa z przodkami w pierwszej Ewangelii ma wskazywać na ujawniające się przez dzieje potomków Abrahama ułomność i złożoność natury ludzkiej. W ich pogmatwane losy włączone jest przez pochodzenie także człowieczeństwo Jezusa.

Egzegeci nie zadowalają się ogólnym rozpoznaniem przynależności Jezusa do ludzkości, lecz starają się bliżej określić konsekwencje tego związku, na które wskazują osobliwe szczegóły wyróżniające Mateuszowy rodowód na tle innych wykazów przodków. W genealogiach biblijnych, podobnie jak w innych starożytnych spisach imion przodków, występują zazwyczaj

19 Por. np. J. Jaromin, Chrystologia, w: Teologia Nowego Testamentu, t. 2: Dzieło Janowe, red. M. Rosik, Wrocław 2008, s. 40-41.

20 Mateusz przedstawia Jezusa jako syna Dawida i syna Abrahama (por. Mt 1,1), różniąc się od Łukasza, który prowadzi genealogię od Niego aż do Adama, syna Boga (por. Łk 3,23-38). 
mężczyźni ${ }^{21}$. Natomiast wymienienie Tamar, Rachab, Rut i żony Uriasza uderza jeszcze z jednego powodu. Pojawiają się one w tej części wykazu imion, w której można byłoby oczekiwać wspomnienia bardziej znanych kobiet, a mianowicie żon patriarchów, które są jednak pominięte. W egzegezie dominują trzy wyjaśnienia funkcji obecności tych mniej znanych kobiet: ich postawa wskazuje na grzeszność rodzaju ludzkiego; ich związki z narodami pogańskimi zapowiadają uniwersalizm misji apostołów; wyjątkowość ich życia zależy od interwencji Boga w ludzkie losy ${ }^{22}$.

Obraz kobiet reprezentujących potomków Abrahama jako grzeszników wydaje się pasować do interpretacji imienia „Jezus”. Wyjaśnienie dane Józefowi przez anioła wiąże misję noszącej to miano osoby z charakterystyką ludu jako mającego grzechy: „Porodzi Syna, któremu nadasz imię Jezus, On bowiem zbawi swój lud od ich grzechów" (Mt 1,21). Grzeszny stan ludzkości nie jest jednak przesłaniem całego rodowodu Jezusa, gdyż na końcu są wymienieni Józef i Maryja, a oblubieniec Matki Jezusa jest scharakteryzowany jako człowiek sprawiedliwy.

Kobietom wymienionym w pierwszych wersetach genealogii jest przypisywane pogańskie pochodzenie. Spoza narodu izraelskiego wywodzą się na pewno dwie z nich: Rachab jest miesz-

${ }^{21}$ Temu patriarchalnemu charakterowi rodowodów nie przeczą przypadki pojawiania się imion kobiet. Ich obecność (np. w Rdz 11,29-31; Wj 6,20.23.25) oznacza, że wymieniona $z$ imienia kobieta odegrała istotną rolę $\mathrm{w}$ dziejach danego pokolenia.

22 Antoni Paciorek przedstawia trzy wyjaśnienia wskazujące na cechy wspólne tej czwórki: grzeszność, pogańskie pochodzenie, wyjątkowość ich życia (A. Paciorek, Ewangelia według świętego Mateusza, część 1: Rozdziały 1-13. Wstęp, przekład z oryginału, komentarz, Częstochowa 2005, s. 82). Józef Homerski wylicza trzy cechy wspólne: zamiast wyjątkowości wskazuje na to, że łączyło je powołanie macierzyńskie (J. Homerski, Ewangelia według św. Mateusza. Wstęp - przekład z oryginału - komentarz, Poznań-Warszawa 1970 [2004 reprint], s. 72). Szerzej na temat argumentacji egzegetów por. A. Malina, Kobiety w genealogii Jezusa (Mt 1,1-17), „Verbum Vitae” 19 (2011), s. 109-129. 
kanką Jerycha; Rut, z powodu swego pochodzenia, nazywana jest kilka razy Moabitką. Ramy narracji o Judzie - oddalił się od braci i wziął za żonę Kananejkę (por. Rdz 38,2) - sugerują pogańskie korzenie także Tamar. Wielokrotne wymienienie imienia Uriasza z przydomkiem Chetyta (por. 2 Sm 11,3.6.17.21.24; 12,9.10; 23,39; $1 \mathrm{Krl}$ 15,5; $1 \mathrm{Krn}$ 11,41) może wskazywać na taką samą przynależność etniczną jego żony Batszeby. Interpretacja o znaczeniu wzmianek kobiet w sensie uniwersalizmu odpowiada otwarciu na pogan w pierwszych dwóch rozdziałach oraz poleceniu misyjnemu wieńczącemu Ewangelię. Ma ona jednak poważny brak. Pogańskiego pochodzenia nie można przypisać piątej kobiecie - Maryi. W narracji następującej bezpośrednio po rodowodzie (por. Mt 1,18-24) wyraźnie uniwersalistyczne przesłanie nie wysuwa się na pierwszy plan $^{23}$. Można je dostrzec w dalszej części opowiadania, a mianowicie w historii o przybyłych mędrcach oddających hołd nowonarodzonemu Jezusowi (por. Mt 2,1-12).

Powyższych braków nie ma interpretacja o wyjątkowości życia kobiet ze względu na Bożą interwencję w ich ludzkie losy. Nie tylko w historiach czterech kobiet, ale również w życiu Maryi ma miejsce taka nieoczekiwana ingerencja. Za każdym razem ujawniają się też trudności w ich relacji do najbliższych im krewnych i środowisk, a zwłaszcza do bliskich im mężczyzn. To wyjaśnienie ma jednak poważny mankament, którego nie miały dwie wcześniejsze interpretacje: wyjątkowość ludzi dzięki interwencji Boga nie jest ani wyraźnym, ani przewodnim motywem w Ewangelii św. Mateusza.

Jakie jest zatem główne przesłanie genealogii Jezusa w związku z Jego człowieczeństwem? Ewangelista wiąże Jego ludzkie pochodzenie $z$ jednym doskonałym planem Boga (trzykrotnie powtórzona liczba czternastu pokoleń), który obejmuje także

${ }^{23}$ Wystarczy porównać zapowiedź zbawienia ludu (por. Mt 1,21; także Łk 1,77) z tekstami czwartej Ewangelii o zbawieniu świata (por. J 3,17; $4,42 ; 12,47)$. 
złożone dzieje ludzi (imiona oznaczające nieraz kręte historie protagonistów). Wzmianki o kobietach wprowadzają temat rozwijany od początku narracji ewangelicznej: człowiek sprawiedliwy wypełnia wolę Boga nawet wbrew własnym planom i zamiarom. Postawa męża Maryi pokazuje, że taka sprawiedliwość ma być tworzywem relacji z Bogiem i ludźmi. Osoby z genealogii nie realizują pełnej sprawiedliwości. Na drogę prowadzącą do takiego jej urzeczywistnienia wkracza Jezus zaraz na początku swojej publicznej działalności, co pokazuje Jego wypowiedź przedstawiona jako pierwsza i skierowana do Jana Chrzciciela: „Trzeba nam wypełniać całą sprawiedliwość" (Mt 3,15). W Jego nauczaniu sprawiedliwość łączy się ze szczególnym darem dla człowieka; darem, który staje się także jego zadaniem, a mianowicie z błogosławieństwami Boga. Na ten zasadniczy temat Ewangelii św. Mateusza wskazuje początek pierwszej mowy Jezusa z błogosławieństwami dla ludzi oddanych sprawiedliwości: „Błogosławieni łaknący i pragnący sprawiedliwości, albowiem oni będą nasyceni" (Mt 5,6); „Błogosławieni, którzy cierpią prześladowanie dla sprawiedliwości, albowiem ich jest królestwo niebios" (Mt 5,10; por. także Mt $5,20 ; 6,1.33 ; 13,49)$. W ostatniej zaś mowie sprawiedliwi, którzy stoją po prawej stronie eschatologicznego Króla, są nazwani błogosławionymi Jego Ojca (por. Mt 25,34.37.46). Jeśli genealogia Jezusa wprowadza do tematu sprawiedliwości, a Jego nauczanie łączy ją z eschatologicznymi błogosławieństwami dla ludzi sprawiedliwych, to również człowieczeństwo Syna Bożego powinno być interpretowane jako wpisane w projekt Boga, rozciągający się od początku stworzenia do końca dziejów zbawienia.

\section{Ostateczna realizacja planu Boga wobec człowieka}

Nie tylko Bóstwo Jezusa, lecz także Jego człowieczeństwo stanowi treść czy przedmiot całego objawienia, a nie tylko jego 
podmiot $^{24}$. Nowy Testament nie ukazuje przyjęcia przez Niego jakiejś „czystej” natury ludzkiej. Mówi natomiast o realizacji planu Boga względem człowieka, który to plan został objawiony już w jego stworzeniu. Księgę Rodzaju otwierają dwa teksty, które choć są świadectwem złożonego procesu powstawania ksiąg biblijnych, to jednak dzięki połączeniu mają też spójne przesłanie. Pierwszy (por. Rdz 1,1-2,4a) pokazuje, że Bóg jest Stwórcą oraz Panem całego stworzenia, który udziela błogosławieństwa na dwa sposoby: bezpośrednio i pośrednio. Istotom stworzonym piątego dnia Bóg błogosławi bezpośrednio (por. $\operatorname{Rdz} 1,22$ ), natomiast spośród istot stworzonych szóstego dnia tylko mężczyzna i kobieta otrzymują błogosławieństwo (por. Rdz 1,28). Stwarzając człowieka na swoje podobieństwo, Bóg ustanawia go współuczestnikiem panowania nad stworzeniem oraz pośrednikiem Bożego błogosławieństwa (por. Rdz 1,26). W drugim opowiadaniu o stworzeniu opisane są negatywne skutki upadku pierwszych ludzi, które zachwiały relacjami z drugim człowiekiem, wprowadziły nieprzyjaźń z częścią stworzenia, ale przede wszystkim radykalnie ograniczyły zdolność do panowania nad ziemią (por. Rdz 2,4b-3,24). Ich wykroczenie polegało nie na spożyciu zakazanego owocu, ale na poddaniu się temu, nad czym człowiek powinien panować. Nie wypełniając powierzonego mu zadania, zdeformował w sobie obraz Boży i podobieństwo do Stwórcy. Dzieje patriarchów pokazują, że Bóg rekonstruuje możliwość odzyskania podobieństwa do Niego i przekazywania w ten sposób błogosławieństwa już nie przez samo panowanie, lecz przez obiecane w przymierzu potomstwo. Projekt panowania nie zostaje jednak całkiem porzucony.

W Starym Testamencie pojawia się określenie „syn człowieka” (viòs àv $\theta \rho \omega ́ \pi o v)$. We wcześniejszych księgach Biblii (por. Rdz 11,5; Lb 23,19; Pwt 32,8; 1 Sm 26,19; 2 Sm 7,14; 1 Krl 8,39; Hi 16,$21 ; 25,6 ; 35,8$ ) oznacza po prostu człowieka (hebr. ben

24 Właśnie o tym pisze Jan: „co ujrzeliśmy własnymi oczami, na co patrzyliśmy i czego dotykały nasze ręce [...] oznajmiamy i wam" (J 1,1-3). 
[hā]'ādām; dosł. dziecko człowieka). W późniejszych tekstach biblijnych i pozabiblijnych, które są świadectwem judaizmu bliskiego czasom Nowego Testamentu, jest natomiast tytułem określającym godność tajemniczej postaci ukazanej jako Syn Człowieka w kontraście do bestii wychodzących z morza i uzurpujących sobie władzę nad ziemią. W języku apokaliptyki przedstawiają one ziemskich pretendentów do władzy nad narodami, którzy dla wierzących w Boga niosą śmiertelne zagrożenie. Wizja zapowiada finał tej walki o panowanie nad światem: „I oto z obłokami niebios przybył jakby Syn Człowieka. Podchodzi do Starowiecznego i wprowadzają Go przed Niego. I zostało Mu dane panowanie, chwała i królestwo, a wszystkie ludy, narody $\mathrm{i}$ języki służyły Mu. Jego panowanie jest panowaniem wiecznym, które nie przeminie, a Jego królestwo nie zostanie zniszczone" (Dn 7,13-14). Dzięki mesjańskiej relekturze tej apokaliptycznej wizji wraz z takim samym odczytywaniem psalmów królewskich (por. zwłaszcza Ps 2; 18; 21; 45; 72; 110) dawna peryfraza staje się tytułem chrystologicznym. Występuje on prawie wyłącznie w Ewangeliach jako samookreślenie Jezusa ${ }^{25}$.

W Ewangeliach synoptycznych tytuł „Syn Człowieka” łączy dwa wymiary egzystencji Jezusa: opisuje w okresie ziemskiej działalności zarówno Jego władzę kontestowaną przez przeciwników (odpuszczania grzechów w Mt 9,6 / Mk 2,10 / Łk 5,24; nad szabatem w Mt 12,8 / Mk 2,28 / Łk 6,5; sądzenia w Mt 16,27-28 / Mk 8,38 / Łk 9,26) ${ }^{26}$, jak i Jego uniżenie w męce i śmierci,

25 Poza nimi pojawia się w wyznaniu kamienowanego Szczepana widzącego Jezusa (por. Dz 7,56).

26 Trudności nie tyle pojawiają się wobec boskiej tożsamości, ile wynikają z ograniczonego poznania Jego człowieczeństwa. Braki w zrozumieniu Jego natury i opór przed przyjęciem wszystkich konsekwencji, co akcentują zwłaszcza Ewangelia Marka i Ewangelia Jana, wynikają z prób przykrojenia człowieczeństwa Jezusa do wyobrażeń i oczekiwań adresatów Jego działalności. Ludzie Nim zainteresowani, jeśli są ograniczeni do takiego horyzontu, nie mogą poznać prawdziwej Jego tożsamości. Napięcia te pokazują, że chrystologia Ewangelii jest zdeterminowana nie tyle 
a następnie wywyższenie w zmartwychwstaniu (por. Mk 8,31 / Łk 9,22; Mt 17,12 / Mk 9,12; Mk 9,31 / Łk 9,44; Mt 20,18-19 / Mk 10,33-34 / Łk 18,31-33; Mt 26,2 / Mk 14,41), zaś po jej zakończeniu wywyższenie w zmartwychwstaniu i paruzji (por. Mt 10,23; 24,37.39.44; 25,31 / Mk 13,26; Mt 26,64 / Mk 14,62).

Ewangelia Mateusza ukazuje Jezusa z atrybutami panującego i dysponującego nadzwyczajną mocą, właśnie kiedy uwydatnia Jego człowieczeństwo. Mędrcy szukają nowonarodzonego Króla, aby mu oddać pokłon (por. Mt 2,2; zob. też Mt 2,8), a gdy Go znajdują, padają przed Nim, realizując swój zamiar (por. Mt 2,11). Kulminacją kuszenia przez diabła, który atakuje od strony ludzkiej, jest najpierw domaganie się od Jezusa pokłonu za królestwa tego świata i jego chwałę - słowa kusiciela nawiązują do Bożej obietnicy złożonej namaszczonemu na króla (por. Mt 4,8-9; zob. też Ps 2,7-8). W odpowiedzi mówi On o Bogu jako wyłącznym adresacie pokłonu (por. Mt 4,10). Trzy narracje odnoszą się do aspektów ludzkich Jezusa ${ }^{27}$, kiedy wzmiankują ten sam gest jako znak rozpoznania Jego władzy nad trądem (por. Mt 8,2), śmiercią (por. Mt 9,18) i demonami (por. Mt 15,25). Kiedy uczniowie

przez tytuły chrystologiczne rozważane same w sobie, ile przez ich włączenie w rozwiniętą i koherentną narrację o działalności Jezusa, odbieranego przez ludzi właśnie jako człowiek. Spośród wielu można przywołać dwa motywy szczególnie zaakcentowane przez wszystkie Ewangelie: odrzucenie historycznego Jezusa przez większość Jego współczesnych, którego kulminacją jest oskarżenie o bluźnierstwo (Mk 2,7: „Czemu On tak mówi? On bluźni. Któż może odpuszczać grzechy, oprócz jednego Boga?”; por. także reakcję mieszkańców Nazaretu w Mk 6,1-6 i par.; J 10,33: „Ty, będąc człowiekiem, czynisz z siebie Boga”); napięcie między niezrozumieniem tożsamości Jezusa przez najbliższych a Jego pedagogią jej odsłaniania, która jest błędnie ujmowana przez tzw. teorię sekretu mesjańskiego (Mk 9,9: „przykazał im, aby nikomu nie rozpowiadali o tym, co widzieli, zanim Syn Człowieczy nie powstanie z martwych"; J 6,60: „A spośród Jego uczniów, którzy to usłyszeli, wielu mówiło: «Trudna jest ta mowa. Któż jej może słuchać?»").

${ }^{27}$ W dwóch pierwszych narracjach cud dokonuje się przez dotyk, zaś w trzeciej matka opętanej tytułuje Jezusa Synem Dawida. 
oddają pokłon Zmartwychwstałemu, wtedy dotykają i widzą Go jako człowieka, a nawet wątpią (por. Mt 28,9.17). O posiadaniu największej władzy mówi na samym końcu On sam jako człowiek: „Jest dana Mi cała władza w niebie i na ziemi. Idźcie więc i czyńcie uczniów ze wszystkich narodów, udzielając im chrztu w imię Ojca i Syna, i Ducha Świętego. Uczcie je zachowywać wszystko, co wam przykazałem. A oto Ja jestem z wami przez wszystkie dni, aż do skończenia świata" (Mt 28,18-20).

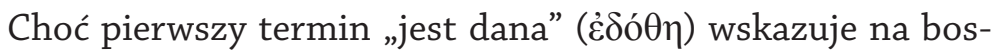
kie pochodzenie i na taki sam charakter władzy, to orzeczenie $z$ dopełnieniem ,jest dana Mi” ( $\dot{\varepsilon} \delta o ́ \theta \eta \mu o \imath)$ oznacza, że Zmartwychwstały przemawia jako Syn Człowieczy, który został zapowiedziany przez wizję Księgi Daniela. Boży plan, aby człowiek panował, jest całkowicie zrealizowany przez Niego, a jednocześnie ma on być kontynuowany przez Jego uczniów. Tę dynamikę oddaje cztery razy powtórzony przymiotnik $\pi \tilde{\alpha} \varsigma$ („cały”, „wszystek"). Najpierw na pełni Jego władzy opiera się realizacja zadań uczniów. Dzięki temu, że cała władza Boska jest powierzona Jezusowi jako człowiekowi, uczniowie przez swoje człowieczeństwo mogą realizować powierzoną misję w zakresie uniwersalnym, czyli w odniesieniu do wszystkich adresatów oraz do całej treści nauczania. Gwarancją skuteczności tego nadzwyczajnego działania jest cały czas trwająca Jego więź z nimi.

\section{Podsumowanie}

W Nowym Testamencie człowieczeństwo Jezusa nie jest przeciwstawione naturze boskiej jak u Filona z Aleksandrii. W genealogiach Mateusz (i Łukasz), pojmując je jako przynależność do obarczonego ułomnościami rodzaju ludzkiego, widzą w tej relacji narzędzie zbawcze. W pierwszej Ewangelii wykaz potomków Abrahama ze wzmiankami kobiet z jednej strony oznacza, że ludzie potrzebują uwolnienia od grzechów, które nie doko- 
nało się ani przez władzę królów (zaczynając od Dawida), ani przez karę niewoli babilońskiej, zaś z drugiej strony wprowadza historię osoby, której ziemskie imię „Jezus” jest zapowiedzią tego wyzwolenia, zaś tytuł „Emmanuel” określeniem sposobu jego realizacji oraz jego owoców. W Ewangeliach synoptycznych wyraźnym odniesieniom do człowieczeństwa Jezusa towarzyszą wypowiedzi o władzy przekazanej Mu przez Boga, co jest rozpoznawane albo kontestowane przez adresatów Jego działalności. Czytelnicy Ewangelii dostrzegają, że w Jezusie jako Synu Człowieka spełnia się plan Boga, aby ludzie przez Jego panowanie otrzymywali i przekazywali innym Jego błogosławieństwo.

\section{Humanity of the Son of God in the Incarnation According to the Synoptics}

The New Testament does not contrast Jesus' humanity with God's nature as Philo of Alexandria makes differences between humanity and divinity. Matthew (and Luke), in their genealogies, identify Jesus' humanity as belonging to the human race burdened with its frailties. The Gospels see His involvement as an instrument of salvation. In the first Gospel, the list of Abraham's descendants with mention of the women, on the one hand, means that all they need to be saved from their sins, what was not accomplished neither by the kings (beginning with David) nor by the punishment in the Babylonian exile, and on the other hand, it introduces the story of a person whose earthly name "Jesus" announces such salvation, and the title "Emmanuel" describes the manner of its realization and its fruits. In the Synoptic Gospels, clear references to Jesus' humanity are accompanied by statements about the authority given to Him by God, which is recognized or contested by the addressees of his activity. The readers realize that in Jesus as in the Son of Man God's plan is fulfilled, so that people through His reign may receive and convey His blessing to others. 